\title{
Motivation in English learning: A Case Study on Language and Literature Students
}

\author{
Valantino A. Pamolango \\ English Language and Literature \\ Department \\ Universitas 17 Agustus 1945 Surabaya \\ Surabaya, Indonesia \\ v.a.pamolangoduntag-sby.ac.id
}

\author{
Adam Trisakti Perwira Alamsyah \\ English Language and Literature \\ Department \\ Universitas 17 Agustus 1945 Surabaya \\ Surabaya, Indonesia \\ adamtrisakti@gmail.com
}

\begin{abstract}
-this research reports the orientations that become the foundations of students' motivation in learning English and their attitude toward courses and their lecturers. The method used is a survey by randomly asking the students at English Department of University of 17 Agustus 1945 (UNTAG) Surabaya to fill out a questionnaire adapted from Attitude Motivation Test Battery (AMTB) designed by R. C. Gardner. This study aimed to uncover the students' orientations in learning English and to see their attitude towards courses and their lecturers. The result shows that out of 60 returned questionnaire, 43 students appear to have not only integrative but also instrumental orientations, 43 students responded positively towards course instructors and 6 of them responded negatively. As for the attitude toward courses, 43 students show positive response while 6 of them seem to have negative one.
\end{abstract}

Keywords: English learning, motivation, and orientation

\section{INTRODUCTION}

There are a lot of things to do in order to increase the quality of English teaching in Indonesia. The ability of students to speak English that has been studied formally can still be concluded as inadequate. Several findings in the field prove such claim, such as students' English language grades that are still below average on national exams, and low frequency of use of English among their peers. Moreover, questionable conditions in university degree also prove this. University students experience difficulties when communicating in English is a must, delivering opinions and also reading textbooks in English. Correspondingly, more attention should be properly given by English teachers in Indonesia in order to increase the quality of English teaching that is effective and accurate, and gives the fact that globalization has reached various life aspects requires the mastery of English language by the community that participates in it.

Various studies and research regarding English teaching and learning in Indonesia have been done much, if not, highly frequent. Several factors that are deemed to have a very significant role in the success of English teaching are teachers, students, curriculum, teaching materials, and learning support facilities. In regard to the students, as one of the important aspects in learning, cannot be seen separately from the discussion of motivation. Motivation for students, to this day, is still believed as the learning aspect that determines the success of student learning. Several research results on motivation in learning foreign languages show that learner's motivation in learning foreign language is a main instigator that leads to the successful learning of that foreign language.

Motivation in learning foreign languages also varies. An individual could learn a foreign language due to the importance of such language, e.g. to earn a job or to study in a country of the aforementioned foreign language which causes the mastery of such language to become a necessity. Furthermore, learning the foreign language due to simply wishing to learn other nation's culture is also possible. Another motivation that often found are the desire to master foreign language, particularly international languages such as English, Mandarin, Deutsch, Japanese and others to facilitate one's effort in earning a job.

As per the importance of motivation itself in learning foreign languages, reference [1] has specifically elaborated within the AMTB research on how important it is to have a good integrative orientation and attitude toward a certain language. A good integrative orientation will help the learner to assimilate better with how a language works and the culture of that certain nation where the language originates. Both of those things are also stated within the research as being particularly useful in the process of mastering a foreign language whereas attitudes of the courses and lecturers are used to determine how effective the studying or the learning procedure for the learners. A good learner will, of course, according to [2], be able to adapt to the environment of the 
courses in order to have a good attitude toward it, but these kinds of learners are particularly hard to find.

Now English is a very important language in world economy development. Untag Surabaya as one of the major private universities in Surabaya has an English Literature and Language department. Students of English department at Untag Surabaya have variable abilities in speaking English. The motivation that sets the foundation for the students in choosing the aforementioned department is also different. Therefore, we would like to conduct a research on the motivation of English department students at Untag Surabaya in learning English language to identify any orientations behind the motivation of students of English department in studying English, and also their attitudes and behaviors toward lecturers and the subjects.

\section{RESEARCH METHOD}

This research is a survey in nature with the spreading of questionnaires that are previously adapted from Attitude Motivation Test Battery (AMTB) whose results are, then, analyzed quantitatively and descriptively. The procedures in this research are as follows:

\section{A. Data Collecting}

Data are collected through questionnaires that are spread to the respondents, which, in this case, are students of English department at Untag Surabaya. The preceding questionnaires are an adaptation of Attitude Motivation Test Battery (AMTB).

\section{B. Respondent}

Respondents are students of English department at Untag Surabaya that originate from four generations: 2013, 2014, 2015 and 2016 to a total of 60 students. Despite the choice of English department as their study program, English, for most of them, remains a foreign language. This is proven by the difficulties that are faced by students of English department in speaking English.

\section{Questionnaire}

Questionnaires consist of four (4) parts, which are:

a. Integrative Orientation (Cultural and Social Goals).

b. Instrument Orientation (Career-related and Academic Goals).

c. Attitudes towards Teachers.

d. Attitudes towards Courses.

\section{DISCUSSION}

Motivation can be defined as an instigator for someone to do a specific task, "Motivation relates to the drive to do something, to study new things, and encourages us to try again when we fail." Reference [3]. In learning foreign languages, reference [4] declares that "Motivation is the feeling nurtured primarily by the classroom teacher in the learning situation as he engages in carefully planned as well as intuitive practices which will satisfy one or more of the basic, universal, cognitive, and affective human needs" (1982).

Reference [2] stated that motivation is an affective variable that should be accounted for in language learning process. Theory of Motivation develops through several periods and perspective. Several perspectives that study motivation are behavioristic perspective that recognizes motivation in the understanding that motivation occurs in response to the desire to acquire rewards. In the cognitive perspective, motivation materializes because of human basic needs. Motivation is seen as decisions made by an individual for the sake of a specific purpose that it wants to achieve reference [2]. Additionally, constructive perspective sees motivation as a product of social construction in the community, a product of individual interaction with its surrounding environment, and also a product that represents as a social status. Another perspective that should be added here is that of Carl Rogers, particularly his humanistic psychology. Reference [2] denotes that in order for someone to "grow", or in this case to increase his or her language proficiency, one has to be given an environment that provides support in openness, acceptance and empathy, most of which are identifiable from the attitudes of students toward a particular learning course or lecturer.

Study related to motivation in learning foreign languages are inseparable from the study done by reference [1]. As in reference [1] examined motivation as a factor for various attitudes which differ one another. Two groups of different attitudes split two basic types that have been identified by Gardner and Lambert as instrumental and integrative orientations to motivation. Reference [1] constructed a measurement tool to gauge students' motivation in learning foreign languages. According to Gardner, the purpose of the foreign language teaching is partly linguistics and non-linguistics. The purpose of linguistics focuses on the individual language proficiency development that incorporates reading, writing, speaking and understanding the foreign language. The measurement tools for this purpose are still few; because of this Gardner developed a measurement tool known as The Attitude/Motivation Test Battery (AMTB). AMTB is focused to study several affective components that influence second language or foreign language learning. AMTB studies language learning in three parts; behaviors, motivation and class anxiety; motivational intensity; teachers and curriculum.

Furthermore, reference [5] said that the classifications of motivation stated by Gardner and Lambert as motivation are not precisely motivation types, but should be seen as orientations instead. This orientation will generate the motivation within the learner. This orientation could be related to academic importance or career (instrumental), or social orientation or cultural (integrative).

From the research accomplished in regard to English learning motivation on students, several data are acquired as follows: 


\section{A. Integrative Orientation (Cultural and Social Goals)}

There are 7 statements given to ascertain whether the English department student has integrative orientation or not:

1. Studying English is important because it makes me more confident.

2. Studying English is important because I can read my favourite novels and watch my favourite movies

3. Studying English is important because I could interact with other people

4. I wish I could have many native English speaking friends.

5. I wish I were fluent in English.

6. I want to better understand and appreciate English Linguistics and Literature

7. I want to learn other cultures and share my culture better.

Total percentage of students' choices when they are confronted with seven statements whose orientation is integrative is as follows; 4 'strongly disagree' voters, 7 'disagree' voters, 6 'abstain' voters, 21 'agree' voters, and 20 'strongly agree' voters, with total of students who missed the questionnaire being 2 . After being calculated, out of 60 students who filled the questionnaires, approximately 43 people could be identified as having integrative orientation and the other 17 as having no such socio-cultural orientation.

\section{B. Instrumental Orientation (Career-Related and Academic Goals)}

In this part, there are five questions to figure out whether English department students have instrumental orientation or not:

1. Studying English is important because I will need it for my future.

2. I wish I could read newspapers, magazines, or even novels in English language

3. Studying English is important because it makes me easier to find a good job.

4. I want to get grade " $A$ " in my English classes all the time.

5. If I could speak English, I will travel abroad more often.

Total percentage of student choices when met with seven statements whose orientation is instrumental is as follows; 0 'strongly disagree' voters, 5 'disagree' voters, 31 'agree' voters, and 17 'strongly agree' voters and a total of 7 people who choose to 'abstain'. After being calculated, out of 60 students who filled the questionnaires, approximately 48 people could be determined as having instrumental orientation and the rest are deemed as having no such orientation or to be determined for being 'abstain'.

\section{Attitudes Towards Teachers}

The next result is in regard to attitude and behavior of students to a subject's lecturer. There are four statements that are served to the students who act as respondent, which are:
1. I love to go to class because my English lecturer is so good.

2. I think my English lecturer is so boring and not good enough.

3. My English lecturer an interesting teaching style.

4. My English lecturer doesn't present materials properly.

In regards to attitudes and behaviors of students to the lecturers, 43 students have positive responses toward lecturers of English Department at Untag Surabaya. Meanwhile the rest, approximately 6 people have negative responses toward their respective lecturers, and the other 11 are left undetermined due to being 'abstain' or missing the aforementioned statements.

\section{Attitudes Towards Courses}

The next analysis results will be based on the attitudes and behaviors toward courses. The questionnaire results for each statement can be seen within the list.

1. I don't pay much attention to the feedback I receive in my English class.

2. My English Skill class is so bored.

3. I do not feel nervous when I have to answer question in English class.

4. I love to spend more time in my English class and less in other classes.

5. I think my English-skill class is good enough.

6. I enjoy the activities of our English class much more than those of my other classes.

7. I do my homework if I had time.

In accordance to the attitudes and behaviours of students toward courses, 43 students exhibited positive responses toward the courses which are taught on English Department at Untag Surabaya. Meanwhile the rest, approximately 6 students has negative responses toward the courses, and the other 11 remained undetermined for being 'abstain' or missing the aforementioned statements.

\section{CONCLUSION AND SUGGESTIONS}

After the survey is concluded using questionnaire for 60 respondents, all of whom are students of English Department at Untag Surabaya, these quantitative analysis results are acquired :

For the integrative orientation, 4 'strongly disagree' voters, 7 'disagree' voters, 6 'abstain' voters, 21 'agree' voters, and 20 'strongly agree' voters, with total of students who missed the questionnaire being 2. After being calculated, out of 60 students who filled the questionnaires, approximately 43 students could be identified as having integrative orientation and the other 17 as having no such sociocultural orientation.

In addition, for the instrumental orientation, 0 'strongly disagree' voters, 5 'disagree' voters, 31 'agree' voters, and 17 'strongly agree' voters and a total of 7 students who choose to 'abstain'. After being calculated, out of 60 students who filled the questionnaires, approximately 48 students could be determined as having instrumental orientation and the 
rest are deemed as having no such orientation or to be determined for being 'abstain'.

In regards to attitudes and behaviors toward teachers, 43 students have positive responses toward lecturers of English Department at Untag Surabaya. Meanwhile the rest, approximately 6 students have negative responses toward their respective lecturers, and the other 11 are left undetermined due to being 'abstain' or missing the aforementioned statements.

Lastly, the attitudes and behaviors toward courses, 43 students exhibited positive responses toward the courses which are taught on English Department at Untag Surabaya. Meanwhile the rest, approximately 6 students has negative responses toward the courses, and the other 11 remained undetermined for being 'abstain' or missing the aforementioned statements.

A conclusion made from such findings is that the average students of English Department at Untag Surabaya have integrative orientation along with instrumental orientation. Other than having sociocultural motivation, they also have motivation that revolves around future careers, education, and jobs, which are hoped, can be earned after finishing the study in English Department. These findings are highly favourable for the process of learning English at Untag Surabaya.

The total percentage of respondents which are classified as having integrative and instrumental orientation highlights the fact that most respondents are willing to learn English as well as assimilating with the culture. These two findings entertain the possibility of a successful learning of English language. And for the most part, it means that having a successful learning of English language will benefit them on the long run to earn a job, a scholarship abroad, a corresponding with foreigners, or other purposes.

On the other hand, the total percentage for the attitudes and behaviors shows that the English Department at Untag Surabaya has managed to facilitate a favorable learning environment. This is proven from most respondents' attitudes toward lecturers and courses alike. Given these findings, it can be concluded that the students in English Department at Untag Surabaya have better chances to master a language based on how they treat the lecturers and the courses, according to Gardner and Lambert's research and to Carl Rogers' humanistic psychology.

The next research should be related to researching the motivation of students out of English Department to study English itself.

\section{Acknowledgment}

We would like to express our high gratitude to the University of 17 Agustus 1945 Surabaya, Indonesia who has fully supported us in having a chance to join this conference. Also, it is for our beloved family in Indonesia and the Netherlands who never stop supporting and loving us.

\section{References}

[1] Gardner, R. \& Lambert, W. 1972. Attitudes and Motivation in Secondary Language Learning. Rowley, M. A: Newbury House.

[2] Gardner, R. C. 1985. The Attitude Motivation Test Battery: Tehcnical Report 1.University of Western Ontario: London. Brown, H.D. 2000. Principles of Language Learning and Teaching. New York. Longman.

[3] Brown, H.D. 2007. Prinsip Pembelajaran dan Pengajaran Bahasa. Edisi Kelima. Pearson Education.

[4] Marlina, Lenny. 2007.Motivation and Language Learning: A Case of EFL Students. Jurnal KOLITA. Unika Atma Jaya.

[5] M. Hines \& W. Rutherford (eds). On TESOL '81. Washington, DC: TESOL

[6] Dornyei,Z. 2001. Teaching and Researching Motivation. England.Longman. 